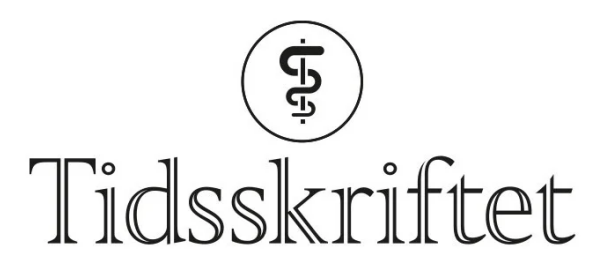

DEN NORSKE LEGEFORENING

\title{
Kardial dysfunksjon ved juvenil dermatomyositt
}

LEGELIVET

THOMAS SCHWARTZ

Email: thomas.schwartz@medisin.uio.no

\section{Ved den revmatiske systemsykdommen juvenil dermatomyositt kan affeksjon av hjertemuskelen være en langtidskomplikasjon. Mulige mekanismer kan være myokarditt eller aterosklerose.}

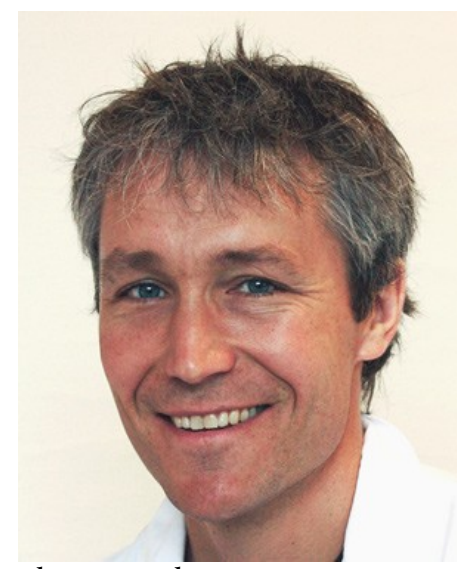

Thomas Schwartz. Foto: Privat

Juvenil dermatomyositt er en sjelden hud- og muskelbetennelse som oppstår i barne- og ungdomsår. Andre organer, som hjertet, kan rammes, men mekanismene for dette er ikke klarlagt. Det er kjent at annen revmatisk sykdom, for eksempel revmatoid artritt, er assosiert med økt kardiovaskulær risiko selv ved lave kolesterolverdier.

Mitt doktorarbeid er basert på en tverrsnittsundersøkelse av de fleste norske pasienter med juvenil dermatomyositt diagnostisert i perioden 1970-2006. Ved ekkokardiografi var det redusert systolisk og diastolisk kardial funksjon hos disse sammenliknet med alders- og kjønnsmatchede kontrollpersoner. Pasientene hadde også økt nivå av kjemokinene MCP-1 og eotaksin, men lavere kolesterolverdier enn kontrollpersonene. Høye nivåer av MCP-1 og eotaksin var assosisert med kardial dysfunksjon hos pasientene, mens assosiasjon mellom 
kardial dysfunksjon og kolesterolverdier i øvre normalområdet bare var til stede hos pasientene med aktiv juvenil dermatomyositt ( $52 \%$ ), ikke hos dem med inaktiv sykdom (48\%) eller hos kontrollpersonene.

Funnene kan tyde på at prematur hjertesykdom, som også er sett ved andre inflammatoriske tilstander, er en langtidseffekt av juvenil dermatomyositt. Risikoen ser ut til å være knyttet til økt inflammasjonsnivå og aktiv sykdom. Forhøyede nivåer av MCP-1 og eotaksin kan medføre eller være uttrykk for senket terskel for ugunstig effekt av kolesterol. Mulige mekanismer for dette kan være lavgradig myokarditt eller aterosklerose i små kar.

\section{Disputas}

Thomas Schwartz disputerte for ph.d.-graden ved Universitetet i Oslo 17.6. 2014. Tittelen på avhandlingen er Cardiac dysfunction and cytokine profile in juvenile dermatomyositis.

Publisert: 25. november 2014. Tidsskr Nor Legeforen. DOI: 10.4045/tidsskr.14.1038

(C) Tidsskrift for Den norske legeforening 2023. Lastet ned fra tidsskriftet.no 26. april 2023. 